\title{
The role of indigenous parataxonomists in botanical inventory: from Herbarium Amboinense to Herbarium Floresense
}

\author{
Jeanine Pfeiffer and Yeremias Uril
}

\begin{abstract}
Pfeiffer, Jeanine ${ }^{1,2}$ and Yeremias Uril ${ }^{3}$ ('1Ethnobotanical Conservation Organization for Southeast Asia (ECO-SEA), Post Office Drawer 1710, Davis, California 95617 USA; ${ }^{2}$ University of California at Davis, Graduate Group in Ecology, Pomology Department, One Shields Avenue, Davis, California 95616 USA; ${ }_{3}^{3}$ Pusat Penelitian dan Pendidikan Masyarakat Tado (P3MT), Kotak Pos 3, Labuan Bajo 86554, Nusa Tenggara Timur, INDONESIA) 2003. The role of indigenous parataxonomists in botanical inventory: from Herbarium Amboinense to Herbarium Floresense. Telopea 10(1) 61-72. The enormous taxonomic scope of the Flora Malesiana Project is exacerbated by the extremely short supply of trained researchers and taxonomic experts available to undertake this task. The vast number of indigenous botanical experts resident in Malesia represents a potentially valuable, yet largely unrecognised and untapped, resource. By engaging in collaborative research with indigenous parataxonomists, Flora Malesiana researchers can develop field methodologies that enable a more comprehensive and accurate assessment of the botanical resources of the region while simultaneously enrolling local communities in the sustainable, long-term conservation of native biocultural diversity. This paper outlines a number of projects involving indigenous research associates, discusses the advantages of developing a network of parataxonomists, and details ways in which botanists and ecologists can incorporate indigenous expertise into biological inventory and conservation.
\end{abstract}

\section{The connection between historical and contemporary herbaria collections}

Three hundred years following the death of Malesia's most famous ethnobiologist, Rumphius [Georg Everhard Rumpf], the first Eastern Indonesian herbarium to be run by an indigenous community was inaugurated by the Tado clan in a small, thatchroofed and bamboo-walled building in the southwestern corner of Flores Island. The Tado are the fifteenth generation descendents of Sulawesi islanders who emigrated from the Makassar sultanate to the Bima sultanate sometime during the 16th or 17th century. Rumphius, the author of Herbarium Amboinense, relied heavily on the knowledge and expertise of the Tado's ancestors during the 17th century to complete his ethnobiological treatise on the region's biodiversity and ethnoecological traditions. In a unique historical reversal, the descendents of those early ethnobiological informants are now curating their own herbarium as part of a larger project to research and conserve their native biocultural diversity and traditional ecological knowledge. In this paper we assign the temporary name 'Herbarium Floresense' to this new herbarium and research project in order to highlight the parallels between the historical and contemporary involvement of Malesian indigenous communities in botanical inventory. The actual name of the site housing the Tado herbarium, ethnobotanical museum, insect collection and resource library is the Tado Community Research and Training Center (Pusat Penelitian dan Pendidikan Masyarakat Tado), part of the Tado Cultural Ecology Conservation Project (Proyek Konservasi Budaya dan Ekologi Masyarakat Tado).

The Tado Cultural Ecology Conservation Project, or TCECP, is the flagship project of the California-based ECO-SEA (Ethnobotanical Conservation Organization for 
Southeast Asia), a non-profit organization focusing on conservation education, ethnoecological research and institutional strengthening. ECO-SEA prioritises partnerships with local, national and international colleagues on collaborative ventures stressing the equitable sharing of responsibility and benefits. In practical terms, this translates into consortium-based project management teams where local community members have equal standing with national or international researchers. Our research teams, composed of both literate and non-literate collaborators, operate within interdisciplinary programs where data is collected, analysed and critiqued by both informants and researchers; seminars and publications are jointly authoured and published; and financial and material resources are equally and transparently shared.

In this article we employ the term 'parataxonomist', a term coined by Daniel Janzen (Janzen et al. 1993) and related to similar terms (e.g., parabiologists, paraecologists) used by ethnoecological projects (Nabhan 2000) to indicate individuals whose specialisation is based primarily on empirical, rather than academic expertise. An indigenous parataxonomist is an individual native to the area in which the specimens or data are being collected who is intimately familiar with the local flora and fauna, and who conducts biodiversity inventories with support from national and international scientists. Parataxonomists work in parallel with taxonomists in collecting, photographing, sorting, preserving and analysing specimens and data, and carrying on the field and laboratory work locally while maintaining contact with taxonomists. In the pages to follow we present a number of case studies where indigenous parataxonomists play a critical role in generating local community support for regional biodiversity conservation networks.

A predominant theme articulated at the Fifth International Flora Malesiana Symposium in Sydney (2001), by plenary speakers from throughout the bioregion, concerned how the overwhelming nature of the ongoing taxonomic inventory of Malesian flora was exacerbated by the extremely short supply of trained researchers and taxonomic experts available to undertake this task. Given current estimates of the taxonomic scope of the Flora Malesiana project (c. 41500 plant species), the taxonomic expertise available (around 130 voluntary collaborators), the average productive lifespan of a given individual (approximately 40 years), the time required to complete a taxonomic monograph for a single species (1-12+ months), and the current rates of habitat destruction in the region, we are literally running out of time. Either the current project collaborators will need to be reincarnated several times over to complete the inventory, or Flora Malesiana is in desperate need of a wider network of collaborators if the project is to be completed within our collective lifetimes.

This point is not new-many of us have made similar ironic calculations-but our intellectual hand-wringing is usually conducted within the hearing of our Englishspeaking, academically trained colleagues. We have not been thinking, or acting, very far 'outside the box.' Given the additional pressing concern that we may be losing an unknown number of species resulting from the ongoing loss of natural habitats in the region, perhaps it is time that our recruitment strategies-the means by which we attract and retain voluntary collaborators-undergo revision. The vast number of indigenous botanical experts scattered throughout the Malesian region-and here we refer primarily to individuals living in rural communities-represent a potentially valuable, yet largely unrecognised and untapped, resource. Yet for almost two millennia, beginning with local inhabitants of the Mediterranean who provided baseline data for the 600 plants described in Dioscorides' De Materia Medica in 77 A.D., indigenous peoples have provided substantive source material for taxonomic research. The empirical importance of indigenous expertise to biodiversity studies as specimen collectors, guides and interpreters of local environments is evident in thousands of published works from naturalists such as Rumphius in the 17th century, 
Linneaus [Carl von Linné] in the 18th century and Alfred R. Wallace in the 19th century. These naturalists relied heavily on indigenous ecological knowledge as a basis for their systematic and theoretical treatises. Ellen and Harris (2000) note that Rumphius' seminal work, Herbarium Amboinense, relied in large part on 'indigenous descriptions of plant ecology, growth patterns and habits,' and that Linneaus 'fully adopted the Cochinese classification and affinities in establishing 240 entirely new species' (Ellen and Harris 2000, p.10). Indigenous residents have also played a critical role in 'scientific' discovery. Some of the more well-known cases include Joseph Arnold's 'discovery' of Amorphophallus and Rafflesia: in both cases, he was led to the plants by native guides (see Bastin 1995 and Zuhud et al. 1998). As Zuhud et al. (1998, p.1) note: 'walaupun Rafflesia telah dikenal oleh penduduk pribumi, akan tetapi deskripsinya ditulis oleh seorang naturalis berkebangsaan Inggris (although Rafflesia was well known by native inhabitants, its description was published by a British naturalist).'

The Malesian bioregion is best documented through long-term, repeated, intimate in situ contact, a practice that is rare among many of those who are affiliated with the 'Flora Malesiana' project. Indigenous experts are frequently sought out by Flora Malesiana researchers to act as guides, informants, and/or collectors, but their contributions to the project are usually curtailed when the researcher departs. Given the difficulty many botanists experience in attempting to collect fertile specimens within the extremely limited time most of us are able to spend in the field, versus the phenological realities of the flora we are attempting to collect (i.e., the sporadic flowering nature of many tropical species), it makes sense to involve local, long-term residents in herbarium specimen collection. Once a specimen is tagged by the botanist, local residents trained in specimen collection and curation-especially farmers, many of whom manage a complex portfolio of varied agricultural plots scattered across several ecosystems-could periodically check on the given plant, and collect the flowers, fruits and seeds when the plant enters its reproductive phase.

Locally trained residents can also provide valuable ecological data for species requiring long-term in situ study. The ecology of intermittently flowering or fruiting plants or those with exceptionally lengthy dormancy periods are difficult to investigate, and hence be understood, by temporarily resident or transient researchers. The familiarity of local residents with the native environment of taxa collected for ex situ conservation is also a valuable resource for scientists attempting to replicate the growing conditions (including associated vegetation, symbiotic organisms, soils and microclimatic conditions) in botanical gardens far removed from the plants' origins.

For those of us focusing on ethnobotanically useful plant species (e.g., plants employed for nutritional, medicinal, social, ceremonial, environmental, agricultural, utilitarian or other economic purposes), the expertise of local residents is the starting point for any ethnobotanical inventory. Thousands of ethnobotanical studies published worldwide for the past millennia, including more recent treatises on the extent of native pharmacoepias (Kreig 1964, Plotkin 1993) have relied on indigenous experts for their baseline data. Yet the authors of such studies are not the owners of the knowledge, and it is usually the collectors and translators of the data who receive the credit. Herein lies yet another conundrum facing the Flora Malesiana project. In a recent submission to the Flora Malesiana Bulletin, $\mathrm{Ng}$ (2002, p. 48) states 'There are almost no contributions from Asian national botanists to the international Flora Malesiana project.' While we would argue this statement underestimates the scientific contributions of national and private universities, herbaria and botanical gardens throughout South-East Asia, the significant disparity between the published taxonomic contributions of 'Western' [non-Asian] botanists versus their Asian counterparts is undeniable. This disparity is due to a complex range of historical, socio-political and economic factors beyond the scope of the 'Flora Malesiana' project, 
but many of those factors (e.g., an inequitable distribution of resources, among others) are present within current conservation projects and continue to perpetuate an inequitable representation of indigenous experts.

The stark contrast between the relative scarcity of scientific resources available to national researchers resident in the centres of floristic biodiversity (in this case we refer to the nations in the Malesian region) versus the wealth of scientific resources available to researchers residing outside the Malesian region was most poignantly illustrated by the plenary presentation at the Fifth International Flora Malesiana Symposium by Osia Gideon on the current state of affairs in Papua New Guinea. Administrative divisions of Papua New Guinea containing floral megadiversity are served by herbaria staffed by a handful of technicians, and an even smaller number of researchers. Despite the impressive volumes of published taxonomic works completed on Papua New Guinea by a number of experts (many of whom were sitting in the audience during the presentation), there is not a corresponding number of trained national researchers who are able to put these taxonomic works to good use. The question begs to be asked: what good are shelves of books and dried specimens stored outside of Malesia, if we fail to make a sustainable investment in the personnel critical to maintaining the wealth of flora inside Malesia? A more proactive approach to human resource development is called for: one example of such an approach can be found in the Parataxonomist Training Center (located in Madang, Papua New Guinea), which is discussed later in this article as a potential template for similar activities within the Flora Malesiana project. (This example, along with our own work, addresses one of the many challenges faced by researchers in the Malesia region: for a more complete treatment of the impediments to flora documentation and conservation in New Guinea, see Conn 1994.)

As scientists, we frequently bemoan the ongoing loss of native habitat and biodiversity, yet note in the same breath that we do not have enough time or resources to simultaneously conduct our research and actively manage conservation projects. A way of achieving both goals involves making a judicious investment in the training and support of locally based counterparts so that they can continue the field research long after the national or international researchers have left the field. By relying primarily on local personnel and materials, successful community-based collaborations are also extremely cost-effective, enabling a more efficient use of limited funds. By engaging in collaborative research with indigenous parataxonomists, Flora Malesiana researchers can develop field methodologies that not only enable a more comprehensive assessment of the botanical resources of the region, but also enroll local communities in the sustainable, long-term conservation of native biodiversity. Indigenous agrarian communities throughout the Malesian region are facing cultural extinction, a process paralleled by the loss of biological diversity on their ancestral lands (Sponsel 2000). As the following section illustrates, many indigenous communities have a deep-seated, long-term interest in documenting and conserving their native biological diversity as a means to ensuring their cultural survival.

\section{The role of indigenous communities in conserving biological diversity}

The Malesian bioregion is renowned not only for its tremendous biodiversity, it is also home to enormous cultural diversity: around 1900 languages (Grimes \& Grimes 2000) are spoken by several thousand ethnic groups inhabiting the region. Each ethnic group is familiar with, and makes use of, different plant assemblages. In addition, each ethnic group has a distinct set of names for the plants used in their culture. Although this linguistic diversity can be a logistical nightmare for a newly arrived botanical researcher (see the following section), the recognition and retention of local biological nomenclature is one of the critical steps to conserving both biological and cultural 
diversity. The naming of native plant taxa is critical to the maintenance of traditional ecological knowledge and local biological diversity: plants that are locally recognised and/or utilised by resident communities are more likely to be conserved, whereas unknown plants are more vulnerable to accidental loss. In turn, conserving the biological reference points for traditional ecological knowledge (e.g., the taxa associated with the knowledge) helps conserve the cultural history of the indigenous community whose cultural traditions incorporate native plants and animals.

Indigenous agrarian communities practicing swidden ('shifting' or 'slash and burn') cultivation in the tropics are frequently faulted for exacerbating habitat and biodiversity loss (Sponsel et al. 1996), but are rarely recognised for their role in maintaining or enhancing species diversity (Barsh 1999). Indigenous peoples have a history of bringing rare plants into cultivation in order to maintain them (Alcorn 1993), or in tending useful herbaceous plant populations in situ (Anderson \& Rowney 1999), promoting population viability and abundance. Backes (2001) and Carrière (2000) have documented the role played by smallholders managing agroforestry systems (homestead gardens, hedgerows, living fences, swidden fields) for the in situ conservation of indigenous trees. Michon et al. (1986) and Aumeeruddy (1995) noted the high species diversity of community-managed agroforestry systems in Sumatra, and the 'natural forest' functions performed by these systems as gene banks and stabilisers against erosion. In describing Ka'apor indigenous forest management in eastern Amazonia, Balée (1994) graphically demonstrated Ka'apor contribution to regional biodiversity: tree species richness in Ka'apor-managed secondary forests following fallow was not significantly different from that of mature forest, and both managed and unmanaged forests accumulated diversity at similar rates. Salick et al. (1999) found a direct relationship between biodiversity maintenance and knowledge of useful plants among the Dusun of Kalimantan (Indonesia).

Indigenous peoples have accumulated several centuries' worth of observational data, much of which is being lost as species become extinct and diverse ecosystems are transformed into monocultures. The efforts to conserve biodiversity need to be in parallel to efforts to conserve traditional ecological knowledge. Senior residents in Eastern Indonesia who can identify an average of 700 plant species (Verheijen 1982) and their associated uses are dying out, while many of the remaining community members find it difficult to recognise any but the most common plants and/or describe the ancestral medicinal and ceremonial practices related to those plants. Researchers working with indigenous communities throughout the Malesian region have published hundreds of studies, but due to the habit of most researchers to work in relative isolation, publish off-site and constantly move on to new areas (Milius 1998), the indigenous owners and managers of this biocultural wealth are often left without the means or methods to effect long-term conservation of the taxa and traditions which are an intrinsic part of their heritage. In the following section we will cite examples of collaborative ventures that involve local communities in the research and conservation of biocultural diversity, and discuss the benefits and challenges of such ventures in greater detail.

\section{Possibilities and challenges in working with indigenous parataxonomists}

As we noted above, despite the widespread acknowledgement of traditional ethnoecological expertise (Slikkerveer 1999), indigenous peoples have rarely been recognised for their potential methodological and theoretical expertise in research and analysis of their ancestral ecological and cultural systems. An efficient means to collecting baseline ecological data involves long-term collaborative research with resident indigenous communities, who can provide extensive empirical data and assist with specimen collection and curation, anthropological and ecological surveys, 
data interpretation and analysis, and editorial review. Traditional ecological knowledge can be incorporated into classical ecological fieldwork exercises such as ecosystem mapping (Robertson et al. 2000), species inventories (Peters 1996), behavioural studies (including competitive, predatory and mutualistic interactions) and historical reconstructions of past anthropogenic and natural disturbances (Martin 1995).

Some of the specific benefits of involving parataxonomists in botanical inventories include:

(a) The collection of higher quality specimens-locals have the time to wait for flowering and fruiting, thus in our case over $90 \%$ of the specimens collected and curated by the Tado are fertile, enabling more accurate taxonomic identification of specimens.

(b) The immediate curation of the specimens (drying, pressing and mounting). Rather than collecting large amounts of material and storing it uncurated indefinitely, Tado research associates collect smaller numbers of specimens and mount and catalogue the dried specimens and associated field notes within a few days or weeks of their collection.

(c) The collection of much more complete data regarding the phenology, ecology, surrounding vegetation, and ethnobotanical importance of the taxa. Bassett et al. (2000) note that parataxonomists are able to complete far higher numbers of ecological observations than the temporarily resident researcher, and 'Because of the high spatial and temporal heterogeneity of ecological factors in rain forests, high numbers of replicate observations, even at the expense of lower accuracy, are likely to shed light on interesting biological patterns' (Bassett et al. 2000, p. 907).

(d) The collection of more accurate and reliable data, especially for taxa which are incorporated into traditional customs. Ian Saem Majnep, of the Kalam people (Papua New Guinea) notes that an 'insider' perspective is advantageous linguistically (many native research associates are bi- or trilingual), socially (local community members are part of an extensive social network of potential informants, including persons possessing very specialised knowledge) and methodologically (community associates have more time to track down information and confirm its veracity) (Majnep with Pawley 2001, pp. 353-354).

(e) The more rapid publication of scientific papers. Following extensive biological inventories in Australia, Papua New Guinea and Guyana, Basset et al. (2000) reported being able to decrease the time-lag between initial data collection and publishing from six to seven years without the involvement of parataxonomists, to two years after parataxonomists were involved.

The first internationally funded project to employ parataxonomists on a large scale is the Costa Rican National Biodiversity Inventory, or INBio project. Since 1989, INBio has provided vocational training to a 'small army' of lay people as parataxonomists in the fundamentals of biology, ecology, taxonomy, evolution, collection and preservation techniques, administration and equipment maintenance, and information management. The parataxonomists collect specimens in 23 biodiversity stations scattered across the country and bring them to INBio on a monthly basis. Upon receiving the specimens, technicians pass the information on to a larger network of national and international taxonomy experts. As of 2000, 127138 plant specimens representing some 8700 species had been collected, in additional to several million collections of vertebrates, invertebrates and microorganisms (INBio 2002). By involving local residents in this national biological inventory, the communities benefit both from the employment opportunities and from the informal education provided 
by the parataxonomists as they disseminate their knowledge to relatives, neighbours, colleagues, and local schools.

Within the Malesia bioregion, the Parataxonomist Training Center in Papua New Guinea has demonstrated the viability of employing indigenous parataxonomists in large-scale, long-term, biodiversity inventories (Novotny et al. 1997). The encyclopaedic ecological knowledge of indigenous Papua New Guineans (reported by Beehler 1994; Majnep with Pawley 2001) has been harnessed for projects affiliated with the Center, and applied to 'the more esoteric ends of basic ecological research' (Basset et al. 2000). By 1997, over 140000 insect specimens had been collected and processed by projects affiliated with the Center, which was established in 1994 following the initial efforts of Larry Orsak at the Christensen Research Institution in 1993-1997. Researchers affiliated with the Center note that the efficiency of fieldwork of village collectors in Papua New Guinea is 'comparable with that of professional ecologists' and allows for the simultaneous collection of specimens at multiple locations (Basset et al. 2000, p. 905). Their biological inventories 'take advantage of three elements: knowledge of the environment by local people; recent developments in computer hardware (e.g., speed and mass storage), which make digital photography a useful tool available at a relatively low cost; and higher data quality due to the increased number of replicates and side experiments performed by the parataxonomists' (Basset et al. 2000, p. 907).

Establishing a new model for collaborative fieldwork requires a combination of experience, planning and commitment, especially if the cooperating parties are separated by several thousand kilometres and an ocean or two. Finalising cooperative agreements (often critical to obtaining internal recognition and/or external funding), obtaining funding and visas to permit the research of international researchers on native lands (or enabling indigenous associates to attend overseas conferences) requires years of advance planning and a vast network of support personnel in both home and host nations. When a large group of data collectors are involved in quantitative surveys, additional statistical tests must be performed to sort out enumerator bias from actual variation in the data observations.

Initial reliance on local nomenclature for documenting ethnobotanical uses must be augmented with the positive identification of voucher specimens, an essential but difficult task due to the lack of a one-to-one correspondence between most folk taxonomies and botanical species circumscribed according to Western scientific principles (a common occurrence in Indonesia and elsewhere: see Berlin 1992, Wilkie \& Saridan 1999) and the infrequent flowering of a number of the tropical forest species. In the past, indigenous knowledge or traditional ecological knowledge systems have been perceived as parallel, but scientifically inferior, observations of the natural world, especially when indigenous classifications do not match the scientific nomenclature. This intellectual elitism is particularly ironic in cases where Western scientists have mistaken anthropogenically constructed ecosystems for 'natural' landscapes, such as the case of forest islands created by the Kayapó in Brazilian savannahs (Posey 1997) or by Kissidougou pastoralists in Guinean grasslands (Fairhead \& Leach 1996). Traditional ecological knowledge may prove critical to researchers working on plant systematics, as historical ecologists are revising long-held definitions of 'natural' vegetation assemblages following research demonstrating centuries-old manipulation of semi-domesticated plant taxa by indigenous forest dwellers (Balée 1994). The sophistication of indigenous ecological classifications has been documented in South America by Fleck and Harder (2000) among the Matses, who distinguish 178 rainforest habitat types, and by the work of Shepard et al. (2001) with the Matsigenka, who delineate 69 vegetationally-defined habitats and 29 abiotically-defined habitats. Yet indigenous ecological terminology tends to vary in meaning and precision, and 
scientists working with indigenous communities need to consider the cultural context of the indigenous knowledge. A recent report comparing indigenous knowledge with external data sources in Chiapas, Mexico (Hellier et al. 1999) resulted in sufficiently contradictory results for the authors to caution against indiscriminate application of indigenous knowledge to biodiversity assessment.

\section{An example of a cross-institutional collaboration}

The Tado clan, whose name is derived from the Tado settlement established by a common ancestor (Pongga) six generations ago, reside in two villages (Golo Leleng, and Nampar Macing) in the Sano Nggoang sub-district, Manggarai district, Flores Island, East Nusa Tenggara province (Indonesia). This province contains the lowest population density (averaging 70 persons $/ \mathrm{km}^{2}$ ) and greatest degree of poverty in Indonesia outside of West Papua (Badan Pusat Statistik 1998; Republic of Indonesia 1991). The island may be poor economically, but it is rich in biological and cultural diversity. The Tado belong to the Kempo Manggarai linguistic group, one of an estimated 30 dialects (Verheijen 1967, 1982) spoken in Manggarai district. There are approximately 25000 plant taxa in Indonesia (Suhirman et al. 1994), and species belonging to over 180 plant families have been identified on Flores (Verheijen 1982, Kebun Raya Eka Karya Bali 1994, Simbolon 1998). A recent ecological survey of protected lowland and montane forests in the Sano Nggoang sub-district documented 20 new plant species and a large number of local endemics (Trainer et al. 2000). Ethnobotanical studies conducted by the Tado have identified several hundred useful plant taxa, but the actual floristic diversity is still unknown. Tado lands contain thousands of ethnobotanically important plant species that are required by the Tado for their livelihood, culture, nutrition, income, animal feed, medicine, rituals, sport, myths and legends. Tado elders repeatedly note the connection between the cultural survival of the Tado and the conservation of the ethnobotanical traditions and associated flora.

Although indigenous agrarian communities in Indonesia are well recognised for their exceptional ethnobotanical expertise (Sorenson and Morris 1997, Balitbang Botani 1998), community members have rarely been recognised for their potential applied, theoretical and methodological expertise in research and analysis of their own ecological and cultural systems. Prior to the initiation of the Tado Cultural Ecology Conservation Project (TCECP), this disjuncture between the potential and actual involvement of local communities was also evident in the area we work in. The extensive botanical work in southwestern and central Flores by two long-term resident priests of the Societas Verbi Divini (SVD) order, namely, Fr. Jilis A.J. Verheijen (1967, 1982) and Fr. Erwin Schmutz (1978-80), has resulted in the flora of Manggarai being among the best documented of the Nusa Tenggara region. They followed standard collection protocols and herbarium specimens collected in the district were stored in Herbarium Bogoriense (BO) and Rijksherbarium (L). As Fr. Schmutz worked in an ecoregion (Mbeliling Forest) immediately adjacent to the Tado's ancestral lands and their Catholic congregation, senior Tado residents were familiar with the priest's fieldwork, but were unaware that he and Fr. Verheijen had published ethnobotanical texts and dictionaries translating Manggarai terms into Bahasa Indonesia and scientific nomenclature.

In an effort to augment the seminal work begun by Fr. Verhiejen and Schmutz, ECOSEA and the Tado have cooperated in a long-term effort to develop an indigenous capacity for conducting ethnoecology research. The Tado Community Training and Research Center was inaugurated in May 2000, and has been equipped with a resource library, herbarium, ethnobotanical museum, scientific equipment and meeting facilities. In addition to training 20 Tado research associates, the TCECP has formalised 
the involvement of Tado traditional and administrative leaders and residents of the 12 Tado settlements into project design, implementation, analysis and review. Thirty-five 'key' informants (18 women and 17 men ranging in ages from early 40s to over 100) and several hundred 'casual' informants participating in group sessions at their respective settlements have been involved in reporting ethnobotanical uses, sharing historical and cultural narratives, qualitative and quantitative data collection, anthropological and ecological surveys, ecosystem transects, and mapping. Now in its fourth year, the results of the TCECP include: (a) the documentation of some 600 ethnobotanical uses for over 300 plant taxa, (b) the curation of several hundred herbarium specimens onsite in the Tado herbarium, (c) the donation of over 170 mounted and databased duplicate specimens to the UC Davis Tucker Herbarium (and another 20 specimens to the Eka Karya Bali Botanic Gardens), (d) the establishment of an ethnobotanical museum onsite containing over fifty artifacts, (e) the joint presentation of research results at three international conferences, (f) the in-house publishing of six booklets on the cultural ecology of the Tado, (g) the joint authorship of three scientific publications, and (h) the generation of a GPS/GIS-based map of Tado ancestral lands.

The immediately apparent benefits to increasing local participation in our ethnobotanical and ecological surveys include the following:

1. We have been able to expand our research scope and to refine our methodological approach based on the collective advice and ongoing input from several hundred community members.

2. The sophistication and rigor of our qualitative and quantitative survey techniques have been easily maintained due to higher levels of comprehension of the research methods by both data collectors and respondents.

3. We have been able to repeatedly cross-check, augment and deepen our ethnoecological and ethnobotanical narratives through a series of peer-review discussions of our research results.

4. We have developed a low-cost, reliable, 'quick-response' link between Indonesia and the USA to exchange data, specimens, reports and other research products on a regular basis. This has greatly increased our collective productivity and administrative efficiency.

5. We have succeeded in recruiting and retaining a core group of Tado research associates and advisors whose professional performance is linked more to personal motivation and pride in their work than to financial benefit.

6. We are able to establish a direct connection between research results and recommendations, and the implementation of those recommendations to conserve elements of biological and cultural diversity within Tado plant and human communities.

Equipping the Tado with the facilities, tools, training, international exposure, and financial means to conserve their biocultural heritage is only the initial phase of ensuring the sustained maintenance of indigenous customs and native taxa. Strengthening Tado administrative capacity is essential, so that the Tado can continue to manage the Tado Community Research and Training Center independently.

\section{Conclusions}

In the words of Robert MacArthur, 'Anyone familiar with the history of science knows it is done in the most astonishing ways by the most improbable people and that its 
only real rules are honesty and validity of logic, and that even these are open to public scrutiny and correction' (MacArthur 1972, p. 259). Just as Rumphius and Linneaus sparked a scientific revolution in the study of biological and cultural diversity with their extensive accounts of ethnoecological variation, the increased involvement of indigenous communities in botanical inventories could spark a parallel revolution in the research and conservation of biocultural diversity. We salute the efforts of institutions such as the Rijksherbarium, the Royal Botanic Gardens Sydney, the Royal Botanic Gardens Kew, Botanic Gardens Conservation International (BGCI), and the Japanese International Cooperation Agency (JICA) in providing substantive support (infrastructure, equipment, consultancies, in-house and overseas training) to their Asian counterparts; as well as the exemplary work carried out by colleagues such as Paul Keßler, Jan Slikkerveer, Gary Martin, and Glenn Wightman, who have prioritised the field training of Asian and Australian researchers and technicians in taxonomy, ecology and ethnobotany. We have benefited from the extraordinary progress made by the PROSEA project in cataloguing and disseminating Malesian ethnobotanical knowledge to the general public.

As we look forward to the Sixth International Flora Malesiana Symposium, to be held in Los Baños, The Philippines in 2004, we invite our colleagues and sister institutions to support the increased participation of indigenous research associates and parataxonomists at these meetings. Since 2001 Tado research associates and advisors have presented project results at international symposia in Australia and the United States, events that have increased civic pride and heightened the community's confidence in their ability to interact professionally in circles previously beyond their reach. ECO-SEA will be sponsoring two delegates from Tado at the upcoming Flora Malesiana symposium, and we hope to facilitate the attendance of several dozen representatives from other indigenous communities affiliated with research projects conducted by Flora Malesiana affiliates. The ongoing exchange between indigenous community members and Flora Malesiana researchers at national and international institutions represents an opportunity for all of us to adhere more closely to the tenets of mutual benefit and responsibility outlined in international conventions such as the 1988 Declaration of Belem by the First International Congress of Ethnobiologists (cited in Martin 1995), the 1992 Convention on Biological Diversity (UNEP-CBD 1994) and the 1993 Principles and Guidelines for the Protection of the Heritage of Indigenous Peoples by the United Nations Working Group on Indigenous Populations (UN-WGIP 1995). We encourage colleagues who are interested in learning of practical ways to apply specific articles of these conventions to their work to contact us directly.

\section{Acknowledgments}

The authors would like to thank Lyn Craven and Glenn Wightman for organizing the ethnobotany mini-symposium at the Fifth International Flora Malesiana Symposium in Sydney, where a preliminary version of this paper was presented bilingually by the authors. Support for the parataxonomy work in Tado has been provided by the U.S. Fulbright Commission and the Davis Botanical Society under the auspices of the Indonesian Institute of Sciences (LIPI). The authors thank Barry Conn, Joy Everett, Peter Wilson and Kevin Rice for their editorial review. The views expressed in this paper are the sole responsibility of the authors. 


\section{References}

Alcorn, J.B. (1993) Indigenous peoples and conservation. Conservation Biology 7(2): 424-426.

Anderson, M.K. \& Rowney, D.L. (1999) The edible plant Dichelostemma capitatum: its vegetative reproduction response to different indigenous harvesting regimes in California. Restoration Ecology 7(3): 231-240.

Aumeeruddy, Y. (1995) Perceiving and managing natural resources in Kerinci, Sumatra. Nature $\mathcal{E}$ Resources 31: 32-36.

Backes, M.M. (2001) The role of indigenous trees for the conservation of biocultural diversity in traditional agroforestry land use systems: the Bungoma case study. Agroforestry Systems 52(2): 119-132.

Badan Pusat Statistik. (1998) Nusa Tenggara Timur Dalam Angka (BPS: Jakarta).

Balée, W. (1994) Footprints in the Forest: Ka'apor Ethnobotany - the Historical Ecology of Plant Utilization by an Amazonian People (Columbia University Press: New York).

Balitbang Botani, (1998) Buku Panduan dan Kumpulan Abstrak Seminar Nasional Etnobotani III, Denpasar, 5-6 Mei 1998 (Puslitbang Biologi, LIPI: Bogor).

Barsh, R.L. (1999) Indigenous knowledge and biodiversity. Pp. 73-76 in Posey, D.A. (ed.), Cultural and Spiritual Values of Biodiversity (Intermediate Technology: London).

Basset, Y., Novotny, V., Miller, S.E. \& Pyle, R. (2000) Quantifying biodiversity: experience with parataxonomists and digital photography in Papua New Guinea and Guyana. BioScience 50(10): 899-908.

Bastin, J. (1995) Sophia Raffles: hardship and travel in Sumatra. Pp. 1-43 in Gullick, J. (ed.), Adventurous Women in Southeast Asia: Six Lives (Oxford University Press: Singapore).

Beehler, B.M. (1994) Using village naturalists for treeplot biodiversity studies. Tropical Biodiversity 2: $333-338$

Berlin, B. (1992) Ethnobiological Classification: Principles of Categorization of Plants and Animals in Traditional Societies (Princeton University Press: Princeton).

Carrière, S.M. (2002) 'Orphan trees of the forest': why do Ntumu farmers of southern Cameroon protect trees in their swidden fields? Journal of Ethnobiology 22(1): 133-162.

Conn, B.J. (1994) Documentation of the flora of New Guinea. In Peng, C.-I. \& Chou, C.H. (eds). 'Biodiversity and terrestrial ecosystems'. Bot. Bull. Academia Sinica Monograph Series 14: 123-156.

Ellen, R. \& Harris, H. (2000) Introduction. Pp. 1-33 in Ellen, R., Parkes, P. and Bicker, A. (eds). Indigenous Environmental Knowledge and Transformations: Critical Anthropological Perspectives (Harwood Academic Publishers: Singapore).

Fairhead, J. \& Leach, M. (1996) Escaping the deforestation mythology. ILEIA Newsletter 12(1): 6-8.

Fleck, D.W. \& Harder, J.D. (2000) Matses Indian rainforest habitat classification and mammalian diversity in Amazonian Peru. Journal of Ethnobiology 20(1): 1-36.

Grimes, B.F. \& Grimes, J.E. (2000) Ethnologue, 14th Edition (SIL International: Dallas).

Hellier, A., Newton, A.C. \& Goana, S.O. (1999) Use of indigenous knowledge for rapidly assessing trends in biodiversity: a case study from Chiapas, Mexico. Biodiversity and Conservation 8(7): 869-889.

INBio. (2002) INBio - Instituto Nacional de Biodiversidad [http://www.inbio.ac.cr/en/default.html]

Janzen, D.H., Hallwachs, W., Jimenez, J. \& R. Gamez (1993) The role of the parataxonomists, inventory managers, and taxonomists in Costa Rica's national biodiversity inventory. Pp. 223-254 in Reid, W.V., Laird, S.A., Meyer, C.A., Gamez, R., Sittenfeld, A., Janzen, D.H., Gollin, M.A. \& Juma, C. (eds), Biodiversity Prospecting: Using Generic Resources for Sustainable Development (World Resources Institute: Washington).

Kebun Raya Eka Karya Bali (Bali Botanic Gardens) (1994) Eksplorasi, Inventarisasi, Penelitian dan Pengembangan Flora di Kabuptaten Ruteng, Flores, NTT (Indonesian Botanic Gardens: Internal circulation).

Kreig, M. (1964) Green Medicine (Bantam Books: New York).

MacArthur, R.H. (1972) Coexistence of species. Pp. 253-259 in Behnke, J. (ed.), Challenging Biological Problems (Oxford University Press: New York).

Majnep, I.S. with Pawley, A. (2001) On the value of ecological knowledge to the Kalam of Papua New Guinea. Pp. 343-357 in Maffi, L. (ed.), On Biocultural Diversity; Linking Language, Knowledge and the Environment (Smithsonian Institution Press: Washington).

Martin, G. (1995) Ethnobotany: a Methods Manual (Chapman \& Hall: London).

Michon, G.F. Mary \& Bompard, J. (1986) Multistoried agroforestry garden system in West Sumatra, Indonesia. Agroforestry Systems 4(4): 315-338. 
Milius, S. (1998) When worlds collide: why can't conservation scientists and indigenous peoples just get along? Science News 154(6): 92-94.

Nabhan, G.P. (2000) Interspecific relationships affecting endangered species recognised by O'odham and Comcáac cultures. Ecological Applications 10(5): 1288-1295.

$\mathrm{Ng}$, F.S.P. (2002) Taxonomy, biodiversity and management of knowledge in Asia. Flora Malesiana Bulletin 13(1): 48-50.

Novotny, V., Basset, Y., Miller, S.E., Allison, A., Samuelson, G.A. \& Orsak, L.J. (1997) The diversity of tropical insect herbivores: an approach to collaborative international research in Papua New Guinea. Pp. 112-125 in Lee, B.H., Choe, J.C. \& Han, H.Y. (eds), Proceedings of the International Conference on Taxonomy and Biodiversity Conservation in the East Asia (Korean Institute for Biodiversity Research of Chonbuk National University: Chonju).

Peters, C.M. (1996) Beyond nomenclature and use: a review of ecological methods for ethnobotanists. Pp. 19-51 in Alexiades, M.N. (ed.), Selected Guidelines for Ethnobotanical Research (The New York Botanical Gardens: New York).

Plotkin, M.J. (1993) Tales of a Shaman's Apprentice: an Ethnobotanist Searches for New Medicines in the Amazon Rain Forest (Penguin Books: New York).

Posey, D.A. (1997) The Kayapó. Pp. 240-254 in IUCN Inter-Commission Task Force on Indigenous Peoples (ed.), Indigenous Peoples and Sustainability: Cases and Actions (International Books: Utrecht).

Republic of Indonesia. (1991) National Census (Central Bureau of Statistics: Jakarta).

Robertson, M., Nichols, P. Horwitz, K. Bradby \& MacKintosh, D. (2000) Environmental narratives and the need for multiple perspectives to restore degraded landscapes in Australia. Ecosystem Health 6(2): 119-133.

Salick, J., Biun, A., Martin, G., Apin, L. \& Beaman, R. (1999) Whence useful plants? A direct relationship between biodiversity and useful plants among the Dusun of Mt. Kinabalu. Biodiversity and Conservation 8(6): 797-818.

Schmutz, E. (1978-1980) Die Flora der Manggarai: Heft 1-5 (Societas Verbi Divini: Ruteng).

Shepard (Jr.), G.H., Yu, D.W., Lizarralde, M. \& Italiano, M. (2001) Rain forest habitat classification among the Matsigenka of the Peruvian Amazon. Journal of Ethnobiology 21(1): 1-38.

Simbolon, H. (Ed.) (1998) The Natural Resources of Flores Island (Research and Development Center for Biology, Indonesian Institute of Sciences: Bogor).

Slikkerveer, L.J. (1999) Ethnoscience, 'TEK,' and its application to conservation. Pp. 169-177 in D. A. Posey (Ed.), Cultural and spiritual values of Biodiversity (Intermediate Technology: London).

Sorenson, K.W., \& Morris, B. (eds) (1997) People and Plants of Kayan Mentarang (World Wide Fund for Nature Indonesia Programme: London).

Sponsel, L.E. (Ed.) (2000) Endangered Peoples of Southeast and East Asia: Struggles to Survive and Thrive (Greenwood Press, Westport).

Sponsel, L.E., Headland, T.N. \& Bailey, R.C. (1996) Tropical Deforestation: the Human Dimension (Columbia University Press: New York).

Suhirman, Butler, G., Fuaddini, Pfeiffer, J., Richardson, M. \& Suhendar (eds) (1994) Strategies for Flora Conservation in Asia (Kebun Raya Indonesia: Bogor).

Trainer, C., Prayito, W., Lesmana, D. \& Gatur, A. (2000) The Biological and Cultural Importance of the Mbeliling Forest for Biodiversity Conservation on Flores (PKA/Birdlife International/WWF: Bogor).

UNEP-CBD (1994) Convention on Biological Diversity. Text and Annexes (UNEP Interim Secretariat for the Convention on Biological Diversity: Genèva).

UN-WGIP (1995) Principles and Guidelines for the Protection of the Heritage of Indigenous Peoples (E/CN.4/Sub.2/1995/26)

Verheijen, J.A.J. (1967) Kamus Manggarai I: Manggarai-Indonesia (Martinus Nijhoff: The Hague).

Verheijen, J.A.J. (1982) Dictionary of Manggarai Plant Names. Pacific Linguistic Series D, no. 43 (Australian National University: Canberra).

Wallace, A.R. (1869) The Malay Archipelago: the Land of the Orang-utan and the Bird of Paradise (Macmillan: London)

Wilkie, P. \& Saridan, A. (1999) The limitations of vernacular names in an inventory study, Central Kalimantan, Indonesia. Biodiversity and Conservation 8(11): 1457-1467.

Zuhud, E.A.M., Hikmat, A. \& Jamil, N. (1998) Rafflesia Indonesia: Keanekaragaman, Ekologi dan Pelestariannya (Institut Pertanian Bogor: Bogor). 